\title{
ANECDOTES OF EARLY LIFE IN INDIANA
}

\author{
By the late Judge Nathan W. Macy
}

(The January, 1928, edition of the Avsals contained a short sketch of the life of Nathan W. Macy in its Notable Death section. His death occurred June 13, 1927. He was one of Nature's noblemen. 'The late H. W. Byers read law in Judge Macy's office. From that period there existed between them bonds of intimacy and tender friendship. Judge Macy was totally blind during the last few years of his life, and consequently had much time to recall his early recollections. Shortly before his death he sent to $\mathrm{Mr}$. Byers the following delightful stories, and $\mathrm{Mr}$. Byers, shortly before his untimely death, handed them to the editor of the Avrals. 'The pertinency in Iowa annals occurs to the vast number of Iowa people descended from Carolina Quaker stock which migrated through the Ohio Valley into Iowa. In Iowa, of the past generation the near kinship of Judge Macy embraced Professor Jesse Macy of Grinnell College and Professor W. P. Macy of Drake University. -Editor.)

Out of memory's depths I make the following memoranda-in part from what my father and others have said, and of which I have had some personal knowledge, and in part from what I have read.

In 1832 my father and mother removed from North Carolina to Henry County, Indiana. There unto them were born seven children, I, being the youngest, on the 25th of March, 1848.

Now and then some one or other of their North Carolina friends would come and see them. On one occasion two came together, one of them was quite portly and the other somewhat slender. The portly friend told my father that he knew he could hold a deer if he could get a good hold on it. My father told them that between there and the river was a large hollow log, and that now and then a deer would come down from the forest on the hills to the river and get a good drink and cool off; and when it started back if the flies were bad it would back into that hollow log and stay until evening, and if our other friend will quietly go away around so he could look thru that $\log$, if he could not see through it, they could be assured a deer was in it and our portly friend here, could go to the head of the log and take his position. And when the deer was disturbed it would 
scramble out, and he could get hold of it as he wished to. This they did, as directed, and when the disturbed deer came scrambling out he got hold of it just as he desired, and his weight broke the deer down to the ground. In a moment it was out from between his legs and was striking at him with its front feet, and one hoof got caught in his shirt and almost tore it off of him. He released his hold and the deer went bounding up to its forest home. He was disappointed and disgusted, but still had faith in the power of his muscle. He shouted to his companion, "Why didn't thee come to my assistance? I could have held it if I'd had a little help." But his companion was so convulsed with laughter at the scene he had witnessed he was not able to give any satisfactory explanation of why he did not go to his companion's aid.

On another occasion a friend came to see them, having with him his rifle. He told my father he hoped that the trip and the stay in that new country would give him additional strength and postpone the final struggle with the dreaded disease, consumption, which had fastened its hold upon his system. He told my father he very much desired to shoot a deer and get some venison, and tell his story to his friends in North Carolina. My father told him that up above about one-half mile there was a branch winding its way down to the river, and that now and then a deer would come browsing down along the branch, and if he would go up there and take the position he desired he could possibly get a shot at one. He did as he was directed and waited in the deathlike silence and sure enough a deer came browsing along. $\mathrm{He}$ waited until the position was satisfactory and then shot, aiming to hit it behind the shoulder. His aim was not accurate and only struck and shattered the shoulder blade. For a moment the deer fell to the ground. The man threw aside his gun and took out his knife and rushed to cut the deer's throat. The deer was at once on its feet and becoming a little accustomed to using its three sound limbs, so as to protect the crippled one, it turned back and thus crippled hurried up to its wooded home. The hunter then tried to find his rifle but could not. He got my father to go up with him and they hunted all around where he said he threw it down, but they could not find it.

The young man returned to his home. Years afterwards a man came to my father and told him that lost rifle was up there and 
a large root of a tree had grown over it and pressed it down into the earth. My father went up and cut off the root and dug up the rifle, but the wooden parts had decayed away. It was not near the place where it was thought to have been thrown aside. Years before this time the young man had made the last struggle for life and had been laid to rest.

My father was night rider on the underground railroad. No fugitive slave that ever came to him was turned back, but was given protection and aid, and was taken to the northwest corner room which was provided with a fireplace and outside door, and there kept until dark when my father would take his team and carriage, with curtains down and the fugitive slave put in the back part, and drive on to the next night-rider's station. There given the recognized signal, that man would come out and receive the slave for his protection and aid, and my father would return home getting there just before daylight. That course was pursued for years.

In 1858 or ' 59 a gravelled pike was built from Knightstown to Greensboro. A short distance below our house there was a knoll over which one could not see down the pike towards Knightstown. About one-half mile above there was another knoll over which one could not see up the pike towards Greensboro. On one occasion my father with the team and carriage was taking mother and the girls down to Knightstown. A short distance below he saw a onehorse buggy coming towards them; the horse was very lame and was being urged forward all the time by the man; the woman was constantly looking back, and at their feet two little colored children nestled. My father drove out to one side so as not to slacken the gait of the buggy of colored folks. A short distance on down two men on jaded horses were coming to meet them, and one said, "Hello, Mister, did you see a buggy of niggers up the Pike?" My father did not stop his team but said, "No," and urged the horses onward. In a moment or two my step-mother said, "Yes, father, we saw that buggy of colored folks just up above," and my father said, "Very well, that is enough on that subject."

My little step-brother and myself were left alone at home, and we were playing towards the pike and we saw the one-horse 
buggy with the colored man with the woman by his side and the children at their feet, and the man urging the lame horse on all the time, while the woman was looking back. In a little while, on jaded horses, two men came along and one was standing up in the stirrups and holding to the mane in front of him.

When my father came home he hastily asked us if we saw the one-horse buggy of colored folks, and also if soon thereafter we saw the two men on horseback. We said yes. He then asked us if we thought the one-horse buggy could get over the knoll above us before the men on horseback came over the knoll below us, and we said yes, we thought so.

Father waited two days and could wait no longer, and then he went up to Greensboro and asked his friends if they saw the buggy of colored people, and they said no. Then he asked if they saw the two men on horseback and they said yes, they were there inquiring all around about the buggy full of "niggers." After awhile they took a road leading down towards the southeast. My father then went out west where he knew there was a man friendly to fugitive slaves. When he got within speaking distance the man said: "Nathan, they got here all right and we kept them two days, doctored up the lame horse, and this morning they started on their way to Canada."

On the back part of his farm John H. Bales caused to be built a one-room log cabin equipped with a fireplace with its crane and bake oven. There lived a colored man and his wife-James and Grace Haskett-known to their friends as Uncle Jim and Aunt Grace. When needed Uncle Jim helped in the farm work among the neighbors-Aunt Grace in the heavy house work among them. Her ability to cook was proverbial and her Carolina biscuits, fried chicken, apple dumplings and pies, with their accompaniments, were regarded without a superior in the culinary line. Aunt Grace lovingly and tenderly waited upon my Mother when I was given life, and she at once announced that I was to be the last and was to be named Nathan after my father. My Father somewhat objected to this and said in a little while I would be known as little Nate and he as big Nate; and later I would be known as young Nate and he as old Nate, but Aunt Grace was inflexible in her judgment and choice. Finally my 
Mother named me Nathan Wilson Macy, her maiden name being Wilson. The last Sabbath we spent in Indiana my brother John and I took dinner with Aunt Grace and Uncle Jim, and oh, what a dinner it was!

When it was time for us to return home, she went with us to the gate. Uncle Jim was out among his poultry and we called to him, "Good-by, Uncle Jim, good-by," and with his thick lips and deep voice he replied, "Good-by, boys, good-by." We then kindly bade Aunt Grace good-by, and she affectionately said, "Good-by, honeys, good-by." When our path turned to be out of sight we looked back and there she stood where we had left her, and we waved our hands to her in a final good-by, and she waved her long apron up and down, and we knew it spoke the language of her heart-"Good-by, honeys, good-by!"

Looking back through the intervening years I am deeply thankful that the love and attachment of Aunt Grace for my mother and father caused me to be given the name I bear. All of my adult life the prayer of my heart has been that I might so live as to be worthy of that name. I shall cherish and bless the memory of Aunt Grace as long as I live.

It was said that George Washington could not tell a lie. I do not believe that the devotion of my father to truth was any less than that of the Father of our Country, and I do not believe that the recording angel recorded the fact that my father said "no" to the human fiends that were seeking to deprive a father and mother and their little children of their rights of liberty and possibly of their right to life.

Abraham Lincoln once said that this nation could not long endure half slave and half free. To him it was given to issue the Emancipation Proclamation and the shackles of bondage fell from millions of people, and in thrilling splendor the stars and stripes wave over the land of the free and the home of the brave.

There lived in Knightstown, Indiana, a Jewish citizen by the name of Mose Heller. One of his countrymen came over to visit nim and during the course of their visit the newcomer said he must go to a barber shop and be barbered. Heller took him to the foot of a stairway and told him to go up and turn in at the door and there he would find the best barber that ever barbered 
him. When he got inside of the barber shop he found the barber was a Negro who politely gave him a seat in the chair and did his preliminary work, including a satisfactory lather of his face. The barber noticed that it was just about 12 o'clock, and not wishing to have any other customers come in and delay his going to his dinner, with the razor in his hand he went and locked the door and turned to come back. The Jew saw in the mirror before him what was done, and sprang from the chair and rushed to an open window and shouted, "My God, murder, Mose, murder!" The barber stood nearby with the razor in his hand and tried to get him to come back and be shaved. Soon a group of men gathered to the place and were much amused at the scene before them. In a minute or two Mose came and it took him quite a while to explain to his friend what the barber meant in locking the door and in getting him to go back and be shaved. Evidently this Jewish newcomer was not accustomed to sccing members of the Negro race held in respect and esteem and occupying responsible positions. Today we have Lawrence C. Jones, a graduate of the State University of Iowa, founding and supporting his Piney Woods School, and with his Cotton Blossom Singers with their Negro melodies delighting multitudes of people who are thus approving and supporting the great work that he is doing for time and eternity.

We have also Roland Hayes leaving his aged black mother in Boston and visiting the principal cities of Europe and by his marvelous voice in song, holding spellbound multitudes of highly cultured and critical hearers. Surely the development and progress of the Negro race is befitting parts of the marvelous development and progress in other lines of thought and activity. 
Copyright of Annals of Iowa is the property of State of Iowa, by \& through the State Historical Society of Iowa and its content may not be copied or emailed to multiple sites or posted to a listserv without the copyright holder's express written permission. However, users may print, download, or email articles for individual use. 